\title{
Effects of Gypsum Soil Amendments on Avocado Growth, Soil Drainage, and Resistance to Phytophthora cinnamomi
}

\author{
B. J. Messenger, J. A. Menge, and E. Pond, Department of Plant Pathology, University of California, Riverside \\ 92521
}

\begin{abstract}
Messenger, B. J., Menge, J. A., and Pond, E. 2000. Effects of gypsum soil amendments on avocado growth, soil drainage, and resistance to Phytophthora cinnamomi. Plant Dis. 84:612-616.

Infection of avocado seedlings by Phytophthora cinnamomi in infested soil was decreased by $71 \%$ by the addition of gypsum soil amendments in replicated greenhouse experiments. Root weights and total seedling weights were not significantly increased by gypsum amendments compared with unamended soil; however, the significant reduction in total seedling weight and root weight caused by $P$. cinnamomi was largely eliminated by the addition of gypsum. Fresh organic matter amendments alone did not significantly affect the total fresh weight or root weight of avocado seedlings. Root fresh weight was decreased in uninfested soil amended with $5 \%$ gypsum and organic matter, but in infested soils, the same treatment increased root fresh weight. Root fresh weight of mature avocado trees in an uninfested grove was not significantly affected by gypsum soil amendments. Avocado seedlings grown in gypsum-amended soil and the roots inoculated with suspensions of Phytophthora cinnamomi zoospores were no more resistant than seedlings grown in unamended soil. Permeability of avocado root membranes, as determined by the amount of ${ }^{86} \mathrm{Rb}$ exuded from root segments over time, was unaffected by growth in gypsum-amended soil. Infiltration of water into soil amended with fine-grade gypsum was impeded initially; whereas soil amended with coarse drywall gypsum drained faster than unamended soil. Drainage was not correlated with root infection of avocados grown in soil infested with $P$. cinnamomi and amended with gypsum. It appears that large reductions in infection of avocado seedlings by P. cinnamomi in gypsum-amended soil are not caused by an avocado growth response, increased root resistance, or reduced root membrane permeability. Infection is not markedly affected by poor drainage when the soil is amended with high levels of gypsum.
\end{abstract}

Phytophthora root rot of avocado, a soilborne disease caused by Phytophthora cinnamomi Rands, continues to be devastating to the cultivation of avocados despite more than 70 years of research on control methods. Phytophthora root rot has been estimated to be present in two-thirds of the avocado groves in California, causing losses of almost $30 \%$ of the total value of the crop (5).

P. cinnamomi most commonly moves into a grove on tools, with infected nursery stock, and with water runoff from nearby sites infested with the pathogen. The pathogen destroys the small, absorbing roots of the avocado, leaving the affected tree with little water uptake ability. The aboveground symptoms of the disease are

Corresponding author: B. J. Messenger

E-mail: bmessenger@agraquest.com

Current address of B. J. Messenger: AgraQuest, Inc., 1530 Drew Avenue, Davis, CA 95616.

Accepted for publication 15 February 2000

Publication no. D-2000-0417-01R

(C) 2000 The American Phytopathological Society not obvious until the roots are heavily infected, and death of the tree usually follows within 1 to 2 years (17). Successful control of Phytophthora root rot has been difficult to achieve, due in part to the poor soil conditions in many California avocado groves. These soils are typically low in organic matter and drain poorly, providing an environment conducive to growth and spread of the pathogen.

The use of rootstocks tolerant to Phytophthora root rot, cultural practices that increase the infiltration of water into the soil, and fungicides can be part of an integrated approach to lower disease incidence and severity. More recently, mulches have been shown to be efficacious in decreasing the level of avocado root rot in field trials (11), using a combination of organic materials similar to the successful Ashburner system used in some Australian avocado groves. The Ashburner system of soil amendments and cover cropping has been shown to create a soil environment suppressive to Phytophthora root rot (4). The factors contributing to this suppressiveness included high levels of exchangeable calcium, high organic matter, and high levels of exchangeable nitrogen. These conditions are not present in most California avocado groves. Amendments that increase the infiltration of water into the soil should decrease disease incidence. Calcareous soil amendments, such as $\mathrm{CaSO}_{4} \cdot 2 \mathrm{H}_{2} \mathrm{O}$, have been shown to decrease avocado root rot in some studies $(6,16)$, although the mode of action has not been determined. It has been proposed that calcareous amendments could decrease disease by increasing water infiltration into the soil.

In this study, gypsum was incorporated into California avocado soil in order to determine whether this calcareous amendment would decrease incidence and severity of root rot in avocado seedlings in a highly controlled greenhouse situation. The effects of gypsum amendments on infiltration of water into the soil, on avocado growth, and on disease resistance were examined in an attempt to explain the disease suppressiveness.

\section{MATERIALS AND METHODS}

Plant material and soil. These studies were performed using seedlings of a commercial avocado rootstock, Persea americana Mill. var. Topa Topa, a cultivar highly susceptible to avocado root rot. Seedlings were grown for at least 11 weeks in vermiculite, and then the roots were gently washed free of planting mix prior to transplanting into the soil mixtures. The soil used in each experiment was a Placentia sandy loam from an avocado grove in Fallbrook, CA, with the following characteristics: $\mathrm{pH}$ (saturated paste) 6.8; electrical conductivity, $2.51 \mathrm{mS} / \mathrm{cm}$; organic matter, $2.43 \%$; and $\mathrm{Ca}, 17.62$ meq/liter. In experiments with infested soil, millet colonized by $P$. cinnamomi was mixed into the soil at a rate of $0.1 \%$ (wt/wt) for $1 \mathrm{~min}$ in a cement mixer. The soil amendments were also mixed into the soil in a cement mixer for $1 \mathrm{~min}$. The avocado seedlings were planted in 2-liter pots and irrigated as needed, approximately three times per week, with dilute (onesixth strength) Hoagland's solution (8). Greenhouse temperatures fluctuated between 18 and $30^{\circ} \mathrm{C}$. All experiments were conducted in greenhouses, with seven replicates per treatment except as noted.

Fungal inoculum. Inoculum for infestation of soil with $P$. cinnamomi was produced by placing mycelial disks into a 
flask containing $50 \mathrm{~g}$ of sterilized millet (autoclaved for $50 \mathrm{~min}$ ) and $25 \mathrm{ml}$ of clarified V8 juice broth (12). Millet cultures were grown at room temperature for 2 to 3 weeks. Formation of sporangia on mycelial mats was induced by a soil extract method (1). The mats were washed with sterile distilled water then kept at $4^{\circ} \mathrm{C}$ for $20 \mathrm{~min}$. The plates were kept at $25^{\circ} \mathrm{C}$ for $1 \mathrm{~h}$ until the zoospores released. The zoospores were harvested and quantified microscopically with a Hawksley eelworm counter (Hawksley, Inc., Lansing, England).

Quantification of infection by root plating. The percentage of the avocado root system that was infected by $P$. cinnamomi was measured after 6 weeks. The roots were thoroughly washed free of soil, and $321-\mathrm{cm}-$ long root tips were excised and plated on a modified version of PARPH, a medium selective for Phytophthora spp. (7). The modifications are as follows (per liter of corn meal agar [Difco Laboratories, Detroit, MI]): $10 \mathrm{mg}$ of pimaricin, $250 \mathrm{mg}$ of ampicillin, $10 \mathrm{mg}$ of rifampicin, $100 \mathrm{mg}$ of pentachloronitrobenzene, and $75 \mathrm{mg}$ of hymexazol. After 2 to 3 days, the root tips were scored for infection based on the growth of $P$. cinnamomi mycelium into the selective medium, and the percent root infection was calculated.

Statistical analyses. Data from each experiment were analyzed by analysis of variance with the general linear model (GLM) procedure and by regression analyses, where appropriate, of the Statistical Analysis System (SAS Institute, Cary, NC). Separation of means was determined by the Waller-Duncan Bayesian $k$-ratio $t$ test. Unless otherwise noted, the data from repeated experiments were analyzed as repeated measures and combined if there was no interaction between experiment and treatment effects.

I. Plant growth and root rot in $P$. cinnamomi-infested and uninfested gypsum-amended soil. Two experiments each were performed with 12 soil treatments. Each treatment included seven replicate avocado seedlings. Pots were placed in a randomized complete block design on the greenhouse benches. Infection by $P$. cinnamomi was determined after the plants were grown in the soil treatments for 6 weeks.

Soil treatments. The 12 soil treatments used in this study were the following: unamended soil (control), 1\% gypsum, 5\% gypsum, $10 \%$ organic matter $(75 \%$ fresh grass clippings, $25 \%$ leaves), $1 \%$ gypsum with $10 \%$ organic matter, and $5 \%$ gypsum with $10 \%$ organic matter (all percentages are dry wt/wt). One-half of the soil in each treatment was infested with $P$. cinnamomi, while the other half was not. After the 6week growing period, the plants were gently washed free of soil and blotted dry. Fresh weights of whole plants and of roots were measured, and root volume was de- termined by water displacement in a graduated cylinder. Root infection was determined at the end of the experiment as described above.

II. Resistance to P. cinnamomi of avocado roots and root membrane permeability. Three repeated trials were conducted in which 10 avocado seedlings per treatment were grown in soil amended with either $0,1,5$, or $10 \%$ gypsum (wt/wt) for 6 weeks. Avocado seedlings grown for 6 weeks in gypsum-amended soils were washed free of soil, weighed, and placed in constantly aerated water in 16-liter buckets. The aeration was turned off while the zoospores were added to the water. Total zoospore concentration was either $3 \times 10^{2}$ or $7 \times 10^{2}$ zoospores per $\mathrm{ml}$. After the root systems were incubated in the aerated zooremoved and blotted dry. Root infection was determined by plating on PARPH, and the percent root infection was calculated.

The effect of calcium on root permeability of avocados grown in gypsumamended soil was examined by measuring the loss of ${ }^{86} \mathrm{Rb}$ (as a tracer for $\mathrm{K}^{+}$) from excised roots (14). Seven avocado seedlings per treatment were grown in soil amended with 0,5 , or $10 \%$ gypsum for 6 weeks in each of two experiments. The plants were washed free of soil, and 151 $\mathrm{cm}$ root segments were excised from each plant. The excised root segments were stored in $0.25 \mathrm{mM} \mathrm{CaCl}{ }_{2}$ holding solution and placed on ice until loading. After all roots were excised, they were placed in an ${ }^{86} \mathrm{Rb}$ loading solution $(0.25 \mathrm{mM} \mathrm{KCl} \mathrm{la-}$ beled with ${ }^{86} \mathrm{Rb}\left[100,000 \mathrm{cpm} / \mu \mathrm{mol} \mathrm{K}^{+}\right]$) and incubated for $4 \mathrm{~h}$ at $30^{\circ} \mathrm{C}$ with conspore suspensions for $24 \mathrm{~h}$, the roots were

tinuous aeration. At the end of the incubation period, each root sample was blotted and placed in a plastic syringe barrel with a rubber tube and a pinch clamp sealing the lower end shut. A 10-ml aliquot of an unlabeled efflux solution $(0.25 \mathrm{mM} \mathrm{KCl}$ and $0.5 \mathrm{mM} \mathrm{CaCl}{ }_{2}$ ) was added to each efflux apparatus, and the system was kept aerated at $25^{\circ} \mathrm{C}$ through the course of the experiment. Every hour for $6 \mathrm{~h}$, the efflux solutions were drained into scintillation vials and then replaced. Total radioactivity was measured with a liquid scintillation counter for each 10-ml efflux sample and for each root sample at the end of the 6-h period.

III. Effect of gypsum amendments on root growth in a mature avocado grove. Eighty Root Ingrowth Cores (Rick-Marx, Frogmore, SC), which are $8 \times 20 \mathrm{~cm}$ perforated plastic tubes, were filled with one of four soil amendments and placed in the feeder root zone of avocado trees in a mature grove on the University of California Riverside campus. The soil amendments were as follows: unamended soil, $1 \%$ gypsum, $5 \%$ gypsum, and $10 \%$ gypsum (all percentages were wt/wt). Four cores were placed around each tree, and each treatment included five trees. The grove was not infested with $P$. cinnamomi. After a 1year period, the Root Ingrowth Cores were dug up, and the roots that had grown into the cores were collected. Root weights were measured, and root volumes were determined by water displacement in a graduated cylinder. Rhizosphere populations of fluorescent pseudomonads were determined by soil dilution plating of the rhizosphere soil onto agar plates of Mannitol Glutamic Acid (9) medium, and fluo-

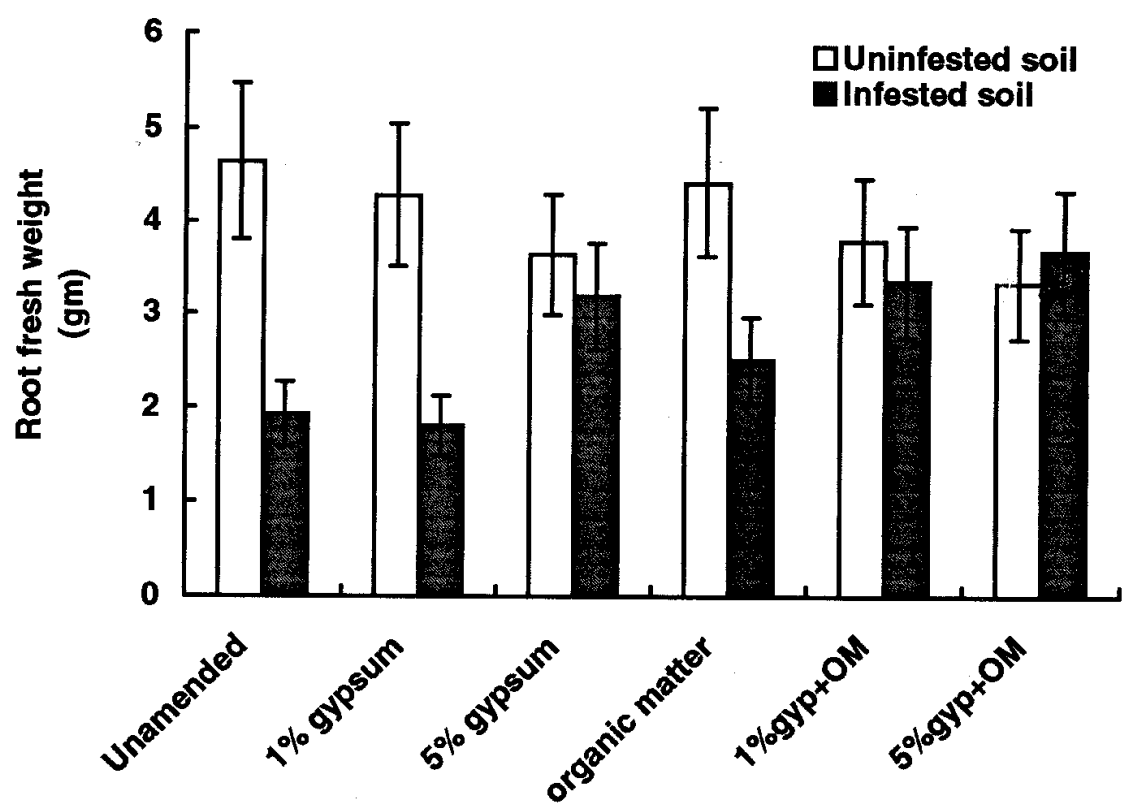

Amendment

Fig. 1. Comparison of root fresh weights of avocado seedlings in infested and uninfested soil amended with gypsum and/or organic matter. Minimum significant difference between treatments was 1.27 according to Waller-Duncan $k$-ratio $t$ test at $k=100$, which approximates $P=0.05$. 
rescent colony-forming units were quantified.

IV. Water infiltration into gypsumamended soil. Five 7-day experiments were conducted using nonsterile field soil in 2liter pots. The soil amendments were 5 and $10 \%$ fine-grade agricultural gypsum, 5 and
$10 \%$ crushed construction drywall, and unamended soil. The soil was placed in pots and watered daily with tap water. At the end of 1 week, the time required for $15 \mathrm{ml}$ of water to percolate into the soil was measured using plastic cylinders $(10 \times 2 \mathrm{~cm})$ with the bottom placed $1 \mathrm{~cm}$ into the soil.

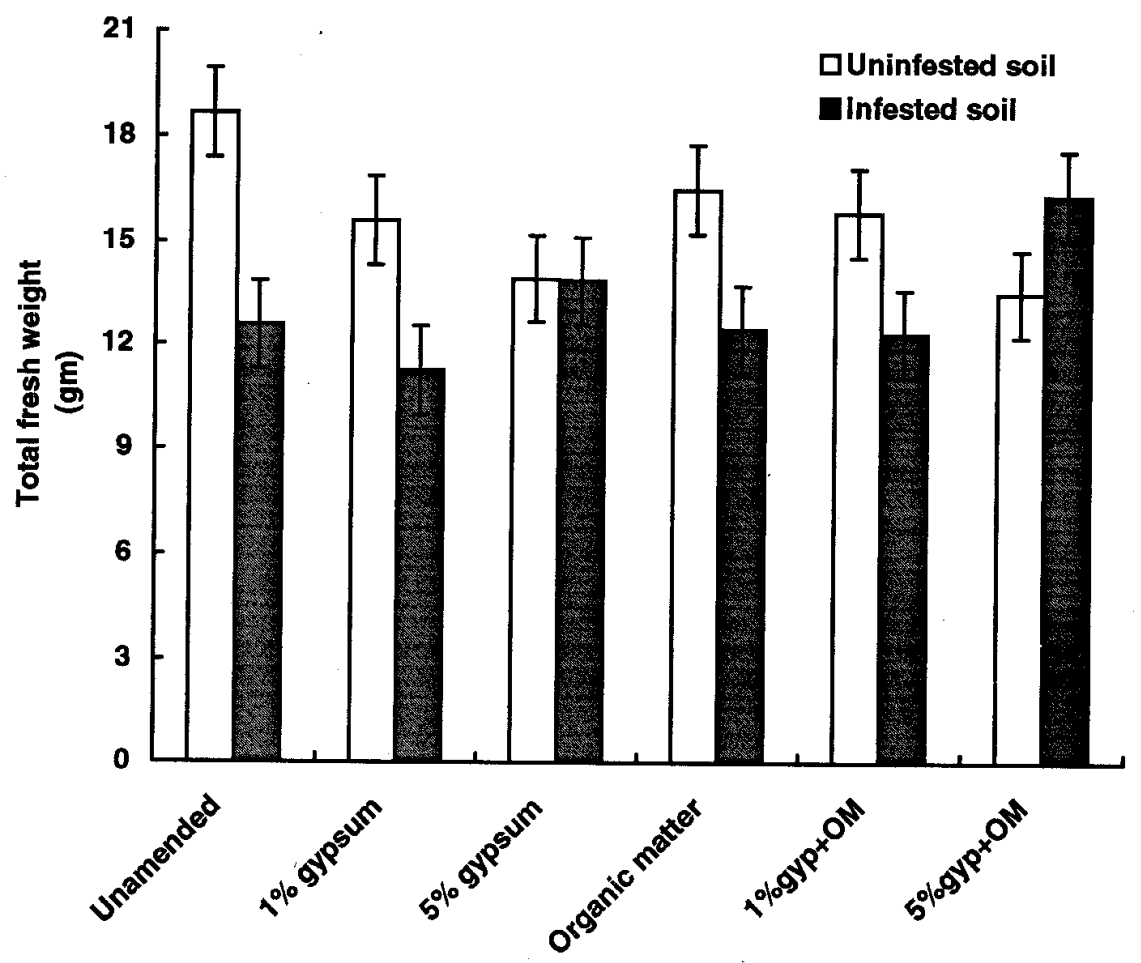

Amendment

Fig. 2. Comparison of total fresh weights of avocado seedlings in infested and uninfested soil amended with gypsum and/or organic matter. Minimum significant difference between treatments was 3.49 according to Waller-Duncan $k$-ratio $t$ test at $k=100$, which approximates $P=0.05$.

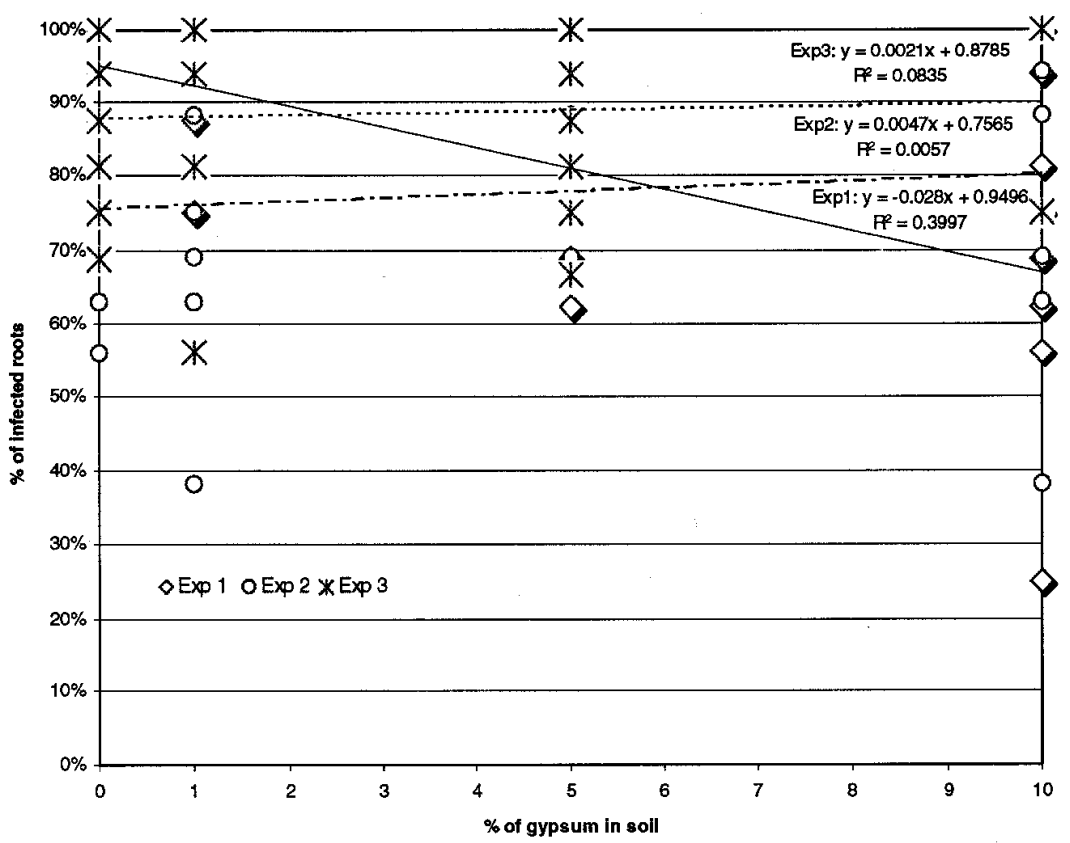

Fig. 3. Relationship between rate of gypsum in soil and percentage of avocado roots infected after removal of roots from soil with zoospores in three trials.

Experiments with avocado seedlings were conducted for 6 weeks using nonsterile $P$. cinnamomi-infested field soil in 2liter pots. The soil amendments were 5 and $10 \%$ fine-grade agricultural gypsum, 5 and $10 \%$ crushed construction drywall, and unamended soil. At the end of 1 week, at week 3 , and at week 5 , the time required for $15 \mathrm{ml}$ of water to percolate into the soil was measured as described previously. After the 6-week growing period, the plants were gently washed free of soil and blotted dry. Fresh weights of the whole plant and of the roots were measured. Root infection was determined as previously described, and the percent root infection was calculated.

\section{RESULTS}

I. Plant growth and root rot in $P$. cinnamomi-infested and -uninfested gypsum-amended soil. Gypsum alone did not significantly affect root growth in uninfested soil, although total fresh weight decreased significantly. Gypsum in combination with organic matter significantly decreased both root and total weight in uninfested soil (Figs. 1 and 2). In soil infested with $P$. cinnamomi, the 5\% gypsum treatment and the treatment combining organic matter and gypsum both showed a significant $(P=0.05)$ increase in total fresh weights and root fresh weight over the control treatment (Figs. 2 and 3). The presence of the pathogen significantly decreased root weight and total weight. Infection of avocado roots by P. cinnamomi was reduced by the addition of either 1 or $5 \%$ gypsum (wt/wt). The addition of $10 \%$ organic matter (vol/wt) alone did not significantly reduce avocado root rot. The treatments combining gypsum with organic matter did not differ from the treatments with gypsum alone in reducing root rot (Table 1).

II. Resistance to $P$. cinnamomi of avocado roots and root membrane permeability. In regression analysis of each of three trials, there was no significant effect on resistance due to the soil treatment $\left(r^{2}=\right.$ $0.08, r^{2}=0.006$, and $r^{2}=0.39$; Fig. 3 ). The difference between trials was not dependent on zoospore concentration. The amount of Rubidium- 86 exuded from roots grown in soil amended with 5 and $10 \%$ gypsum was not different from the amount of $\mathrm{Ru}-$ bidium-86 exuded from roots grown in unamended soil in two experiments. We cannot conclude that root membrane permeability changed in seedlings grown in gypsum-amended soil (Fig. 3).

III. Effect of gypsum amendments on root growth in a mature avocado grove. The root weights and volumes showed no statistically significant difference between the soil amended with gypsum and unamended soil. The populations of fluorescent pseudomonads in the rhizosphere also did not vary between treatments.

IV. Water infiltration into gypsumamended soil. Soil amended with $10 \%$ 
drywall gypsum drained at the same rate as the unamended soil. Fine-grade gypsum appeared to significantly impeded drainage (Tables 2 and 3). After 5 weeks of irrigation, the fine-grade gypsum amendments drained as fast or faster than the unamended soil. The root infection was greatest in the unamended soil. Root infection in soil amended with either form of gypsum was reduced significantly over the unamended soil (Table 3).

\section{DISCUSSION}

Greenhouse studies using P. cinnamomiinfested, gypsum-amended soil from a California avocado grove showed that gypsum can reduce avocado root rot in California as well as in Australia $(4,6,16)$ under controlled conditions. The previous work was frequently anecdotal or failed to address the causes of decreased infection in gypsum-amended soils. This work examined some of the proposed causes and found none of them to be significant under greenhouse conditions.

Gypsum has been proposed to increase avocado root resistance to Phytophthora root rot. This was based on work on the role of calcium in host resistance in systems involving fungal and bacterial polygalacturonases, although it has not been studied previously in the avocado root rot pathosystem. Bean hypocotyls became more resistant to polygalacturonase as

Table 1. Effect of gypsum soil amendments on root infection in infested soil in two replicated greenhouse experiments

\begin{tabular}{lc}
\hline Soil amendment & $\begin{array}{c}\text { Percent root } \\
\text { infection }^{\mathbf{y}}\end{array}$ \\
\hline Unamended & $46 \mathrm{a}^{\mathrm{z}}$ \\
$1 \%$ gypsum & $34 \mathrm{~b}$ \\
$5 \%$ gypsum & $13 \mathrm{c}$ \\
$10 \%$ organic matter & $36 \mathrm{ab}$ \\
$1 \%$ gypsum, & $34 \mathrm{~b}$ \\
$10 \%$ organic matter & $32 \mathrm{~b}$ \\
$5 \%$ gypsum, & \\
$10 \%$ organic matter & \\
\hline
\end{tabular}

$y$ Values represent the mean of twenty replications from two merged experiments.

${ }^{\mathrm{z}}$ Means followed by the same letter are not significantly different $(P=0.05)$.

Table 2. The effect of gypsum on infiltration rate of water into unamended soil or soil amended with gypsum in two replicated lathhouse trials ${ }^{y}$

\begin{tabular}{lc}
\hline Soil amendment & $\begin{array}{c}\text { Time for } \mathbf{3 0} \text { ml of } \\
\text { water to drain into } \\
\text { soil (min) }\end{array}$ \\
\hline Unamended & $9.6 \mathrm{~d}^{\mathrm{z}}$ \\
$5 \%$ fine-grade gypsum & $37.5 \mathrm{a}$ \\
10\% fine-grade gypsum & $24.9 \mathrm{~b}$ \\
$5 \%$ drywall gypsum & $17.3 \mathrm{c}$ \\
10\% drywall gypsum & $9.4 \mathrm{~d}$ \\
\hline
\end{tabular}

y Values represent the mean of 14 replications from two merged experiments.

${ }^{\mathrm{z}}$ Means followed by the same letter are not significantly different $(P=0.05)$. calcium pectate replaced the pectin in the cell wall upon maturity (2). Polygalacturonase, a pectic enzyme responsible for maceration of the plant tissue, is released by Phytophthora capsici during cyst germination and has been shown to contribute to both virulence and fungal nutrition in the intercellular spaces of host tissue (15). Polygalacturonase and other pectolytic enzymes are also produced as extracellular metabolites by Phytophthora infestans (13). In our studies, root rot incidence was decreased in gypsum-amended soil, but root resistance to infection by zoospores did not appear to be affected. As expected, we saw no effect on growth with gypsum soil amendments since there is adequate calcium present in these soils, as in most California soils. The addition of calcium, in the form of a gypsum soil amendment, did not have a great effect on growth or resistance, possibly because the avocado seedlings were not grown under calciumdeficient conditions.

The amount of root exudates has been shown to be a factor in the resistance of some avocado rootstocks to $P$. cinnamomi (3); however, the membrane permeability, an indication of total root exudates, of the Topa Topa rootstock was not significantly affected by growth in gypsum-amended soil. These results do not preclude a calcium-mediated decrease in the amount of a specific exudate, such as aspartic acid, which would be undetected with the membrane permeability method we used, but which would certainly affect disease resistance. Zoospores are preferentially attracted to aspartic acid and glutamic acid over other root exudates (10), and an increase in the exudation of one of those amino acids would result in increased attraction of zoospores to the roots.

Improved soil drainage is the most often cited reason for decrease in infection in gypsum-amended soil $(4,6,11,16)$. The addition of gypsum increases water infiltration by deflocculating clay particles in high-sodium soils and so does not improve drainage in all soils. In our work, the infiltration rate of water into soil was initially slowed by the addition of fine-grade gypsum to the soil, although the drywall gypsum sometimes speeded up the infiltration rate. The soil used was not high in sodium, so increased drainage through deflocculation of clay particles was not the cause of the faster infiltration rate. The drywall gypsum was added as chunks of material measuring up to $1 \mathrm{~cm}$ in diameter. The addition of these chunks could have increased soil porosity by increasing the size of drainage channels through the soil. Despite the impeded drainage in the slowerdraining fine-grade gypsum, the root infection of avocado seedlings grown in the gypsum-amended, P. cinnamomi-infested soil did not increase as predicted. This seems to indicate that the presence of gypsum in the soil strongly affects the disease incidence independently of any effects on drainage of water through the soil.

Gypsum soil amendments significantly reduced root rot in avocado seedlings in greenhouse experiments. The cause of this reduction is not entirely clear from these tests. Increased plant growth is eliminated as a significant factor, since gypsum amendments frequently reduced root growth in uninfested soil. Root exudation was unaffected, although levels of specific exudates were not measured. The effects on water infiltration depended on the particle size of the gypsum amendment, rather than on a reaction between gypsum and soil particles. The addition of gypsum seemed to reduce root rot regardless of whether the soil drainage was good or poor, although root rot is often reduced in well-drained soils. Finally, growing the plants in gypsum-amended soil did not increase root resistance to $P$. cinnamomi infection. The effect of gypsum on growth and reproduction of the pathogen itself may shed more light on the mechanisms of gypsum-induced disease reduction in avocado.

\section{LITERATURE CITED}

1. Ayers, W. A., and Zentmyer, G. A. 1971. Effect of soil solution and two soil pseudomonads on sporangium production by $P$ hytophthora cinnamomi. Phytopathology 61:1188-1193.

2. Bateman, D. F., and Lumsden, R. D. 1965 Relation of calcium content and nature of the pectic substances in bean hypocotyls of different ages to susceptibility to an isolate of Rhizoctonia solani. Phytopathology 55:734738.

3. Botha, T., and Kotze, J. M. 1989. Exudates of avocado rootstocks and their possible role in resistance to P. cinnamomi. S. Afr. Avocado Growers' Assoc. Yearb. 12:64-65.

4. Broadbent, P., and Baker, K. F. 1974. Behavior of Phytophthora cinnamomi in soils suppressive and conducive to root rot. Aust. J.

Table 3. Root infection of plants grown in gypsum-amended soil with different infiltration rates in greenhouse experiments ${ }^{\mathrm{y}}$

\begin{tabular}{|c|c|c|c|c|c|}
\hline \multirow[b]{2}{*}{ Soil amendment } & \multicolumn{4}{|c|}{ Time for $\mathbf{3 0} \mathbf{~ m l}$ of water to drain into soil (min) } & \multirow{2}{*}{$\begin{array}{c}\% \text { root } \\
\text { infection }\end{array}$} \\
\hline & week 1 & week 3 & week 5 & Average & \\
\hline Unamended & $19.0 \mathrm{a}^{\mathrm{z}}$ & $56.8 \mathrm{a}$ & $73.8 \mathrm{a}$ & $49.9 \mathrm{a}$ & $32.56 \mathrm{a}$ \\
\hline $5 \%$ fine-grade gypsum & $26.0 \mathrm{a}$ & $61.5 \mathrm{a}$ & $52.8 \mathrm{ab}$ & $43.1 \mathrm{ab}$ & $14.19 \mathrm{~b}$ \\
\hline $10 \%$ fine-grade gypsum & $18.8 \mathrm{a}$ & $62.5 \mathrm{a}$ & $57.1 \mathrm{ab}$ & $43.6 \mathrm{ab}$ & $8.38 \mathrm{~b}$ \\
\hline $5 \%$ drywall & $10.9 \mathrm{a}$ & $34.6 \mathrm{a}$ & $38.6 \mathrm{~b}$ & $31.7 \mathrm{~b}$ & $14.38 \mathrm{~b}$ \\
\hline $10 \%$ drywall & $7.4 \mathrm{a}$ & $43.9 \mathrm{a}$ & $35.4 \mathrm{~b}$ & $30.9 \mathrm{~b}$ & $10.07 \mathrm{~b}$ \\
\hline
\end{tabular}

y Values represent the mean of 14 replications from two merged experiments.

${ }^{\mathrm{z}}$ Means followed by the same letter are not significantly different $(P=0.05)$. 
Agric. Res. 25:121-137.

5. Coffey, M. D. 1987. Phytophthora root rot of avocado: An integrated approach to control in California. Plant Dis. 71:1046-1052.

6. Falcon, A., Fox, R. L., and Trujillo, E. E. 1984. Interactions of soil $\mathrm{pH}$, nutrients and moisture on Phytophthora root rot of avocado. Plant Soil 81:165-176.

7. Gees, R., and Coffey, M. D. 1989. Evaluation of a strain of Myrothecium roridum as a potential biocontrol agent against Phytophthora cinnamomi. Phytopathology 79:1079-1084.

8. Hoagland, D. R., and Arnon, D. I. 1938. The water culture method for growing plants without soil. Calif. Agric. Exp. Stn. Circ. 347.

9. Keane, P. J., Kerr, A., and New, P. B. 1970. Crown gall of stone fruit: Part 2: Identification and nomenclature of Agrobacterium isolates. Aust. J. Biol. Sci. 23:585-595.
10. Khew, K. L., and Zentmyer, G. A. 1973. Chemotactic response of zoospores of five species of Phytophthora. Phytopathology 63:1511-1517.

11. Menge, J. A., Ohr, H. D., Johnson, E. L. V., Campbell, S., Guillemet, F., Grech, N., and Pond, E. 1994. The effect of mulches, gypsum and fungicides on the performance of avocado planted in soil with Phytophthora cinnamomi and Phytophthora citricola. (Abstr.) Phytopathology 84:1103.

12. Menyonga, J. M., and Tsao, P. H. 1966. Production of zoospore suspensions of Phytophthora parasitica. Phytopathology 56:359-360.

13. Protsenko, M. A., Vasil'eva, K. V., Ladyzhenskaya, E. P., Gladikh, T. A., Glinka, E. M., and Shaposhnikov, G. L. 1991. Study of interaction between extracellular metabolites of Phytophthora infestans and cytoplasmic membranes from potato tubers. Prikl. Biokhim. Mikrobiol. 27:411-421.

14. Ratnayake, M., Leonard, R. T., and Menge, J. A. 1978. Root exudation in relation to supply of phosphorus and its possible relevance to mycorrhizal formation. New Phytol. 81:543552.

15. Sanchez, L. M., Doke, N., Ban, Y., and Kawakita, K. 1994. Involvement of suppressorglucans and plant epidermal cells in host-selective pathogenesis of Phytophthora capsici. J. Phytopathol. 140:153-164.

16. Trochoulias, T., Broadbent, P., and Baigent, D. R. 1986. Response of avocado to calcareous and organic amendments. Acta Hortic. 175:179-181.

17. Zentmeyer, G. A. 1980. Phytophthora cinnamomi and the Diseases It Causes. American Phytopathological Society, St. Paul, MN. 